\title{
The Implementation of Natural Semantic Metalanuage and Semantic Field in Language Teaching: A Case Study
}

\author{
Nengah Arnawa \\ Faculty of Language and Arts Education, IKIP PGRI Bali, Seroja Street, Tonja, North Denpasar, Bali, Indonesia
}

\begin{abstract}
This study aimed at developing a model of learning Balinese vocabularies by implementing Natural Semantic Meta-language (NSM) and semantics field theory. This finding was expected to establish a natural atmosphere of Balinese learning based on semantics primes. Semantics primes development on the basis of semantic field can overcome abstractness meaning of certain words. To prove the truth of the theory construction, the researcher modified a research and development which refers to Borg and Gell models. Data were collected before and after the development of model with certain indicators: the rapid in understanding words meaning, skill in using the word in natural sentence structure, and students' learning creativity. Significance was measured by using t-test formula for correlated samples. Based on statistical analysis, it was proved that the implementation of NSM and semantic field theory was very effective (significant) in learning Balinese vocabularies on students grade 1, 2, and 3. Effectiveness of learning was achieved because the materials adhering to the natural principle of language acquisition and the availability of direct meaning comparison between words were intuitively related. Direct comparison could overcome the cognitive limitations of students grade 1,2 , and 3 in primary school.
\end{abstract}

Index Terms —natural semantic metalanguage, semantics primes, semanitc field, input hypothesis

\section{INTRODUCTION}

There are more than 800 languages in Indonesia one of which is Balinese language. The existence of Balinese language is very apprehensive. The apprehension to the Balinese language has been proposed by researchers and language observers who predicted that the language is nearly dead. The anxiety is based on the number of the language speaker is getting decreased. Indonesian statistics agency reports that declaim in number of Balinese speaker have been $1 \%$ every year (Alwi and Sugondo, 2003). Another fact also revealed that $71 \%$ of Balinese speaker are old people and only 29\% are children (Wiguna, at al, 2015). The number gives a very clear signal that a language death has happened. This phenomenon could be a fact if there is no revitalization effort.

A lot of revitalization effort has been done by government of Bali Province. Some of Balinese language revitalization concrete efforts, are: (1) recruiting contract counselors of Balinese language who are assigned at desa pakraman 'tradition village', (2) promoting Balinese lesson as a compulsory local content at all levels and kinds of school, and (3) giving authority to regent and mayor to appoint professional Balinese teachers. Those revitalization effort was affixed in Regulation of Bali Province Territory Number 3 year 1992 and Regulation of Bali Governor Number 20 year 2013. The effort has not been successful to overcome declaim in number of Balinese active speakers which is predicted only one million people from four million of population of Bali island, as launched via Bali Post local media, dated 15 March 2008 by The Head of Culture Department of Bali Province (Sumatika, 2008).

The data above clearly indicates crucial point that Balinese language construction was laid on children speakers which the number is getting declined. Therefore, Balinese language construction orientation needs to be focused for Elementary students, especially the first three grade. Nevertheless informal education track, Balinese language construction does not seem to show good result yet. From a short interview that undertaken classically to 114 elementary students, $83 \%$ of the respondent stated that Balinese language is such a difficult lesson and is not interesting. This fact encourages the developmental effort on Balinese language learning materials to be more accomodative and relevant to students needs.

The needs on a more accomodative Balinese language learning materials is felt to be very urgent in paradox empirical condition. The paradox condition is triggered by the unsuitable learning materials with linguistic competence, language needs, and the students' environment. Justification of unsuitable learning materials is pursuant to Arnawa's study (2005) result that children at 4-6 years old are not relatively ready to learn Bahasa Bali Alus 'respect style of Balinese'. However, the subject has been a compulsory material as implied in text book of Kusumasari 1 for the first grade students of Elementary school between 6-7 years old average. This material choice is not suitable with input hypothesis which clarifies that language learning will be effective if study material is higher one level than leaner's competence at that time that is going on naturally (Krashen and Terrell, 1983). Another language fact contributing to study material imbalance is the materials choice commonly used by Balinese speakers. Balinese vocabulary learning 
materials are dominated with archaic words, such as: bebedag 'small horse', wiwi 'small goat', apa 'small monkey', tai 'kitten', etc. The vocabulary teaching will be stopped in the students' cognitive level because it is not applicated in Balinese language usage naturally considering the main purpose of Balinese language teaching is to improve chidren' skill in speaking Balinese language (Disdikpora Provinsi Bali, 2006). Sosiologically and culturally, Balinese language skill improvement has strategic value. Sociologically, Balinese language is an ethnic identity that also builds Indonesian diversity. Culturally, Balinese language has its literature and letters. The sosiological and cultural value encourage more specific concrate effort so that Balinese learning effectivity in elementary level can be realized. One of the convincing efforts is improving the effectivity of Balinese vocabulary learning by implementing natural semantic metalinguistic theory (NSM) and semantic field.

\section{THEORETICAL CONSTRUCTION}

Natural semantic metalanguage theory (NSM) clarifies that there is a meaning set on every unchange language. The meaning set is first mastered by a child at the time when language acquisition occurs. The meaning set is called as semantics primes (Goddard, 1996). Semantics primes is presented with a set of word. Semantics primes can be clarified into semantic prototype, such as: substantives, determines, quantifiers, evaluators, descriptors, mental predicates, speech, action-events-movement, existance and possession, life and death, times, space, logical concepts, intensifier, augmentor, taxonomi-partonomy, and similarity (Wierzbicka, 1996). Every semantic prototype encompasses semantics primes element in different number. The total number of the semantics primes element is about 60 . By the 60 semantics primes, the children Balinese vocabulary which is connecting intuitively can be developed.

This NSM concept is in accordance with semantic achievement hypothesis. In this hypothesis, it is clarified that children semantic development and general cognitive development is connected by semantics primes that is representing category or principal to classify thing or situation (Chaer, 2003). For development need of Balinese vocabulary study material model, the words that represent the semantics primes, such as dingeh 'hear', neneng 'see', kisid 'move', gede 'big', besik 'one', rasa 'feel' and others can be used as reference for the children vocabulary development. Then, every word presenting the semantics primes is derived to produce another vocabulary which meaning is still intuitively related to the semantics primes. For example, the word nengneng 'see' can be derived into the word balih 'watch, iwasin 'observe', sledet 'glance', delok 'view', intip 'peep at', tolih 'look toward by turning the head', delik 'look at with big eyes', dengeng'stared wide-eyed, and some others. Derivative meaning explication is standing on semantics primes. Such as the word balih means nengneng igel-igelan 'watching artshow', tolih means nengneng ke samping 'stare at to left or right', intip means 'seeing while hiding', and so on. Another concept from NSM theory which has practicable value in Balinese vocabulary teaching is allolexy. Allolexy is identical with synonym, that is different word but it is used to present the same semantics primes. Different word choice is caused by distribution factor (Wierzbicka, 1996). Distribution variation example of the use semantics primes, nengneng and cingak, which both have meaning 'see' is found in the following sentence:

(1) Melahang nganengneng apang enggal dueg!

Good-suf pre- look so that quick understand.

'Look carefully so that you can understand quickly'

(2) Becikang nyingak mangda gelis wikan!

Good-suf pre-look so that quick smart.

'Look carefully so that you can understand quickly'

The verb nyingak in sentence (2) is an alolexy of the verb nganengneng in sentence (1). The use of the verb nyingakin in sentence (2) is caused by its distribution with another word which is kruna alus 'respectful variation word'. Distribution variety of the use Balinese semantics primes is hoped to be able to enrich children vocabulary contextually. Semantics primes application from this NSM theory can be used as pedal of children Balinese vocabulary development more purposively and functionally.

NSM theory application in vocabulary learning is integrated with semantic field theory. Both relations are linear and complete one another because they stand on the same philosophy basis, i.e. word meaning derivation is centered at semantic core. Meaning field concept is visualized as lexical circle which is built by semantic association net and inter word relation contact. The inter word relation is formed naturally in cognitive map because vocabulary of a language is arranged in mosaic of meaning field (Parera, 1990:67-70). The relation inter word can be patterned into two, that is nature reality picture and culture. Nature reality is naturalistic fact that is not the result of learning. The word pasih 'sea' and danu 'lake' are two Balinese words which presents nature reality, while culture meaning field is a learning result reality that is presented through word, like the word ketipat 'rice cake boiled' and capil 'hat'.

Nature and culture reality is realized through a set of word through collocation and set. Collocation refers to semantic and domain bound existence while set refers to paradigmatic relation. Paradigmatic relation is characterized by the existence of inter word substitution potential (Harimurti, 1993).

NSM theory and semantic field is implemented in Balinese vocabulary learning through the forming of semantic field circle by placing semantics primes derivation elements as development center. The use of semantics primes element as center of semantic field is based on basic assumption that the meaning element is first mastered by a kid at language acquisition (Wierzbicka, 1996; Goddard, 1997). The combination of both theories is operationally done by 
determining a semantics primes as the semantic center which is further is developed by collocation principal and set, which is part of semantic field theory. For example, a teacher determines semantics primes $a b a$ 'bring' as semantic center that furthermore together with children is developed based on semantic field principal. Semantic derivation of semantics primes $a b a$ 'bring' produce some words which the meaning is center on $a b a$, for example: suwun has alolexy with sunggi 'bringing something on head', sangkol 'bringing something by lapping in front of the body, sangkil 'bringing something by lapping on the left or right side of the body', gandong 'bringing somebody on the back', tikul 'bringing something on the back of shoulder,' gandeng 'bringing something on the back by bike or motorbike', tegen 'bringing something on the shoulder', singal 'bringing a baby on the waist,' gosong 'bringing something by lifting equal with stomach' (Warna, and friends 1978). The next step, the students together with the teacher make natural sentence by using the semantics primes derivation vocabulary $a b a$ 'bring' suitable as Balinese morphosyntaxis norm, such as the following example.
(3). I Meme nyuun sok.
Art mother pre-carries basket
'Mother carries basket on the head'
(4). I Putu negen tambah.
Art Name pre-carries hoe
'I Putu carries hoe on the shoulde'.

By such procedure, Balinese vocabulary development involves kid cognitive process through semantic classification analogy. The essence of classification is a summary and a simplification (Sumarsono, 2004). The application of NSM theory and semantic field is suitable as vocabulary teaching approach, that is lead the students to classify new words and make sharper difference about vocabulary they have known (Tarigan, 1986). The application of NSM and semantic field in Balinese vocabulary learning like this is suitable as language learning basic principal.

Empiric condition above encourages the effort of arranging Balinese vocabulary development program for Elementary Students grade 1,2, and 3, that up to now have never been done. This research is designed to get the aim. Explicitly this research intends to develop learning model of Balinese vocabulary. The developed teaching model of Balinese vocabulary is hoped as vocabulary teaching prototype of others local language in Indonesia.

\section{METHOD}

This research is designed with research and development design in education field. The result hoped from this research is a development model of Balinese vocabulary learning material suitable with learning needs for Elementary School students, grade 1, 2, and 3. To get the result, this study implementation refers to Borg and Gall (1983) development research model modified to be four steps, they are: (1) planning, (2) model development, (3) model try out, and (4) model revision. The planning stage includes problem analysis. Problem analysis was done through students' perception quarrying about Balinese teaching and learning achieving. Perception quarrying was done with short interview (classical) to Elementary Student grade 1, 2, and 3. Recognizing learning achievement was done with vocabulary test.

Data found in the planning stage became basis for designing product of Balinese vocabulary learning materials. Learning material was designed by using semantic primes as the center of semantics which is developed in meaning field circle. Prior to the try out, the design was validated by an expert judge of Balinese language. The design is tried out in a limitedly at Elementary School 6 Dalung, Kuta Utara, Badung, Bali, Indonesia. The locus was chosen as the characteristic of the students was very heterogeneous. The limited try out result was used as the base for revision of the model. This level 2 revision result was also validated by an expert before being tried out more widely. Research was done in the form of brainstorming. Input obtained in brainstorming became pedal to revise the model before being determined as a model product of Balinese vocabulary teaching for Elementary Student grade 1, 2, and 3.

Model effectiveness was measured by comparing learning result on both pre test and post test. The effectiveness indicator was (1) students' speed in comprehending word meaning, (2) students' skill in using vocabulary in natural sentence structure, and (3) students' learning creativity. Every indicator has score ranged from 1 to 4 . Score 1 means very ineffective, while score 4 means very effective. Testing was done by some steps: (a) determining the number of respondent (60 students); (b) counting maximum score (4 x 3 x $60=720$ ); (c) counting maximum score for each instrument item $(4$ x $60=240)$; and $(d)$ checking significance by using t-test formula. If the post test score higher than pre test, then the developed model is declared effective (Sugiono, 2012).

\section{RESEARCH RESULT}

\section{A. Balinese Vocabulary Teaching Prior to Model Development}

Prior to model development, vocabulary teaching refers to the book Kusumasari as the compulsory reference. This book consists of 6 volumes which is suitable as the level number in Elementary School. The Book Kusumasari 1, 2, and 3 are used for Balinese lesson grade 1, 2, and 3 of the Elementary School. In Kusumasari book 1, vocabulary material choice is focused on (1) part of human body, such as bok 'hair', mata 'eye', alis 'eyebrow', cunguh 'nose' (common variety of Balinese vocabulary) and prabu/duur 'head', karna 'ear', kanta 'neck' (respective variety of Balinese 
vocabulary); (2) daily food group, such as: be 'fish/meat', jukut 'vegetable', sambel 'sauce'; (3) household equipment, such as: dampar 'bench', kekeb 'clay steamer lid', dangdang 'large metal vessel for steaming rice', kuskusan 'bamboo plaited for steaming', and siut ' wooden hoarsing tool'; (4) clothes classification, such as udeng head gear', saput 'waist clothes', slempod 'shawl', baju 'shirt', and topi 'hat'. In Book Kusumasari 1, Balinese vocabulary is thought by referential approach, where the students are introduced by word reference that is thought. Reference introduction is done directly or using picture media. Teaching vocabulary about parts of human body is thought by point toward parts of their own body. In this book, learning material arrangement of Balinese vocabulary was generally done partially, i.e. vocabulary is thought autonomously as a morpheme unity and the use is only a few trained in a natural sentence

Semantic relation tungkalikan 'antonym' such as: anteng 'diligent' its antonym is mayus 'lazy', cenik 'small' its antonym is gede 'big' is the first vocabulary material which is loaded in book Kusumasari 2. The second material is kruna alus 'respect variety word' on Balinese costume domain, such as destar, kuaca 'shirt', umpal 'shawl', kampuh 'waist clothes', wastra 'cloth'. The third material is about agriculture equipment, such as: lampit 'harrow', tenggala 'plow', singkal 'part of plow that pierce wedge', kejen 'plow eye', uga 'the tool that hook the cows/bulls when plowing, srampang 'hoe', etcetera. The fourth material is synonym, for example rurubin its synonym is tekepin 'is covered', pedih its synonym is gedeg 'marah'. The use of some vocabularies has been thought in sentence, but its lexicon meaning is not explained yet. As the result the students' memorize word and sentence without understand its meaning and using.

In book Kusumasari 3, Balinese vocabulary study material is begun by synonym, such as patut, its synonym is beneh 'benar', uug, its synonym is benyah 'broken', ngranang, its synonym is makada 'cause', and so on. Furthermore it is followed by anggah ungguhing basa 'speech levels' in Balinese, such as negak (common) its polite word is mlinggih 'sit down', ngigel (common) its polite word is masolah 'menari', mulih (common), its polite word is budal 'come home', etcetera. Balinese speech level seems more dominate the study material choice in book Kusumasari 3.

Based on document registration toward book Kusumasari 1, 2, and 3 found data: (1) vocabulary choice is done randomly without estimating the center and semantic field; (2) vocabulary choice is not suitable with students communication needs because vocabulary material is chosen based on prescription of adult speaker (teacher), (3) vocabulary meaning that is thought is not explained yet based on nature language semantic feature. All of those facts seem contribute toward the low result and Balinese learning motivation of the students. Based on testing result on study material model predevelopment that study material development effectiveness so far is used 0,315 or $31,5 \%$ with learning indicator achievement level such as the following: (1) the word meaning understanding speed level of students grade 1,2 , and 3 is 0,36 or $36 \%$; (2) the using skill of vocabulary in nature sentence structure is 0,288 or $28,8 \%$; and (3) student learning creativity is 0,296 or $29,6 \%$. This empirical condition would like to be improved through this research.

\section{B. Development of NSM and Semantic Field-based Balinese Language Vocabulary Learning Model}

The average age of Elementary Student grade 1, 2, and 3 are 6- 8 years old. Seeing from the cognitive development, the children in those ages are at the end of preoperational phase and enter the beginning of concrete operational phase (Sund, 1976 and Chaer, 2003). In this period, the child linguistic competence development is featured by : (1) the ability of presenting object and event, (2) the ability of developing cognitive structure, (3) the ability of developing sentence structure, and (4) the ability of implementing grammatical rule (Owens, 1992). To support the linguistic competence, the children need appropriate vocabulary so that they able to express the action and object that arranged into a simple sentence. The action and object is happened and exist around the children. The action that dominates the children life in age 6-8 years is playing and socializing with their friends in the same age. The need object is nature things to fulfill socializing needs.

Based on language needs analysis of Elementary Students grade 1, 2, and 3, Balinese vocabulary teaching model that is based on natural semantic meta-language theory (NSM). In this NSM theory, semantic centering is found in certain lexicons that presenting primitive meaning or semantics primes (Wierzbicka, 1996b and Goddard, 1997). Orienting to grade 1,2, and 3 and by standing on NSM theory, so that semantics core list is formulated that is becoming integral part of Balinese teaching, such as: awak 'body', anu 'something', luung 'good', gede 'big', tawang 'tahu', mrasa 'feel', ngomong 'say', mlaksana 'doing', kadaden 'happened', kisid 'move', ngelah 'have', pidan 'moment', tongos 'place'. Furthermore, every semantics core is developed by semantic field theory.

NSM theory implementation and semantic field will produce a very dynamic lexicon pattern. For example, when the semantics primes awak 'badan' is developed by semantic field, it will produce word list such as: mata 'eye', kuping 'ear', cunguh 'nose', layah 'tongue', gigi 'tooth', etcetera. If the word mata is described semantically, it will produce canonic sentence pattern (1) Mata bagian awak ane anggo ninggalin 'Eye is the part of the body to see' and (2) Ninggalin nawang anu nganggo mata 'Seeing is knowing omething by using eyes'. Therefore, it is illustrated clearly that there is semantic field between eye and knowledge. Vocabulary development program that is based on NSM theory and semantic field is parallel with basic principal of children cognitive development that is children knowledge expansion through outside world absorption by using five senses (Sujiono, at. al., 2006).

NSM theory implementation and semantic field in Balinese vocabulary teaching that is visualized with lexicon circle. The word that presents semantic primes become semantic center that will be developed by meaning close principal in semantic field, such as the following example. 


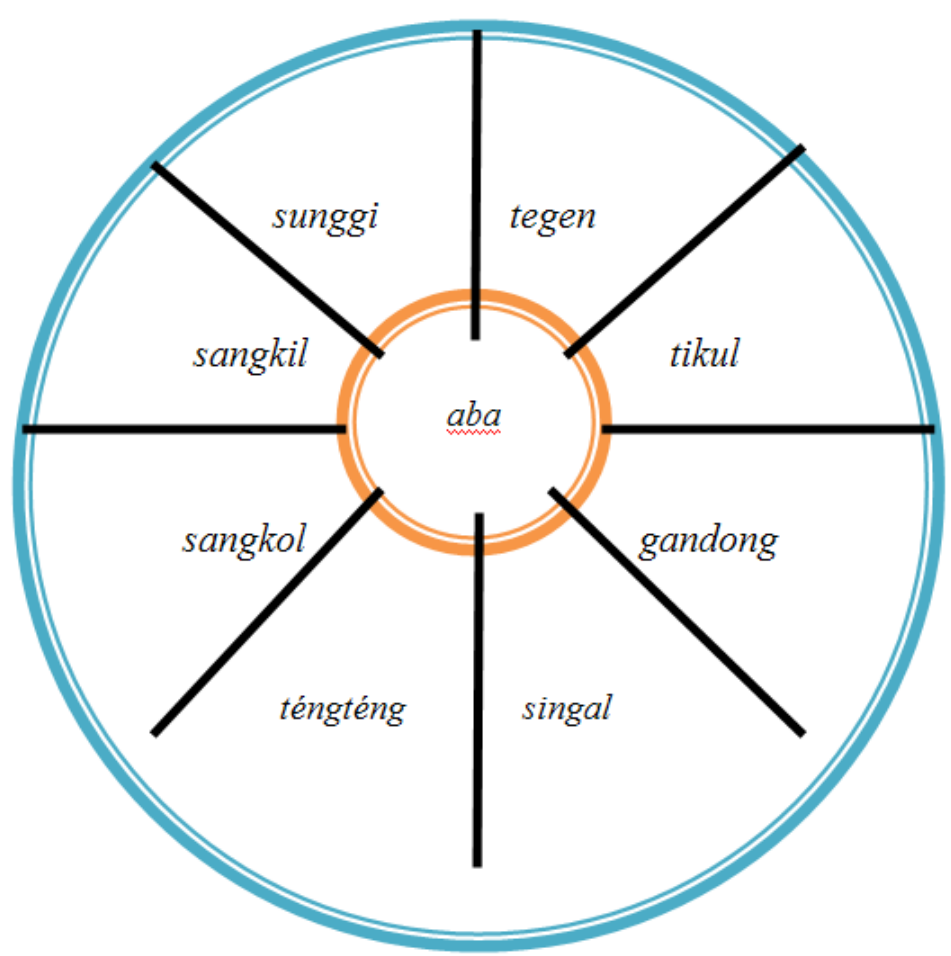

Figure 1. Dynamic Model of Balinese Vocabulary Development

The figure 1 above shows the word $a b a$ 'bring' located in the center of circle is a semantic prime element and the words around are its semantic derivation that is developed based on lexicon semantic field principal. The semantic field circle can explain the meaning of each word that surround semantics primes. For example, sunggi, aba aji sirah 'bringing on head'; tegen, aba aji bau 'bringing on shoulder'; tikul, aba aji durin bau, 'bringing on the back of shoulder'; gandong, aba aji tundun 'bringing on the back'; singal, aba panak di bangkiang 'bring a kid on waist'; tengteng, aba aji lima beneng tuun 'bringing by hand downward'; sangkol, aba aji lima makadadua di malun awak 'bringing by both hands in front of the body'; sangkil, aba disamping aji lima aneh 'bringing at the side with a hand'; etcetera. By vocabulary developing model like that, a student can compare the difference more detail and the similarity of vocabulary semantics that exist in one semantic field.

Furthermore, every vocabulary that have been learned was used in nature sentence, for example: I Putu nengteng layangan 'I Putu is holding a kite'; I Made ngandong I Komang, 'I Made carries I Komang on the back'; and so on.

Based on test result of Balinese vocabulary development which bases on NMS theory and semantic field it was drawn that the effectiveness of Balinese vocabulary learning materials development model of Elementary Students grade 1,2 , and 3 was 0,738 or $73,8 \%$ with achievement indicator as follows. (1) speed level of word meaning comprehension was 0,717 or $71,7 \%$; (2) vocabulary using skill in nature sentence structure was 0,738 or $73,8 \%$; and (3) students' learning creativity was 0,758 or $75,8 \%$. Furthermore, significance of research result test was done by the following step.

(1) Test of Model Predevelopment Data Normality

TABLE 1.

TEST OF MODEL PREDEVELOPMENT DATA NORMALITY

\begin{tabular}{|c|c|c|c|c|c|c|c|c|c|}
\hline \multirow{2}{*}{$\begin{array}{l}\text { No } \\
1 \\
\end{array}$} & \multirow{2}{*}{$\begin{array}{l}\text { Classification } \\
\overline{\mathrm{X}}_{-3 \mathrm{SD}}-\overline{\mathrm{X}}_{-2 \mathrm{SD}}\end{array}$} & \multicolumn{3}{|c|}{ Interval Class (IC) } & \multirow{2}{*}{$\begin{array}{l}f_{o} \\
0\end{array}$} & \multirow{2}{*}{$\frac{f_{e}}{1,2}$} & \multirow{2}{*}{$\begin{array}{l}f_{o}-f_{e} \\
-1,2\end{array}$} & \multirow{2}{*}{$\frac{\left(\mathrm{f}_{\mathrm{o}}-\mathrm{f}_{\mathrm{e}}\right)^{2}}{1,44}$} & \multirow{2}{*}{$\frac{\frac{\left(f_{o}-f_{e}\right)^{2}}{f_{e}}}{1,20}$} \\
\hline & & 0,42 & & 1,54 & & & & & \\
\hline 2 & $\bar{X}_{-2 S D}-\bar{X}_{-1 S D}$ & 1,54 & - & 2,66 & 7 & 8,4 & $-1,4$ & 1,96 & 0,23 \\
\hline 3 & $\overline{\mathrm{X}}_{-1 \mathrm{SD}}-\overline{\mathrm{X}}$ & 2,66 & - & 3,78 & 28 & 20,4 & 7,6 & 57,76 & 2,83 \\
\hline 4 & $\overline{\mathrm{X}}-\overline{\mathrm{X}}_{+1 \mathrm{SD}}$ & 3,78 & 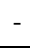 & 4,90 & 11 & 20,4 & $-9,4$ & 88,36 & 4,33 \\
\hline 5 & $\overline{\mathrm{X}}_{+1 \mathrm{SD}}-\overline{\mathrm{X}}_{+2 \mathrm{SD}}$ & 4,90 & - & 6,03 & 12 & 8,4 & 3,6 & 12,96 & 1,54 \\
\hline 6 & $\overline{\mathrm{X}}_{+2 \mathrm{SD}}-\overline{\mathrm{X}}_{+3 \mathrm{SD}}$ & 6,03 & - & 7,15 & 2 & 1,2 & 0,8 & 0,64 & 0,53 \\
\hline \multicolumn{5}{|c|}{ Total } & 60 & 60 & & & 10,67 \\
\hline
\end{tabular}

From the analysis result, it was obtained that gained $\chi^{2}$ stat in the amount of 10,67 while $\chi^{2}$ table part with $\mathrm{df}=6-1=$ 5 and significance standard 2,5\% shows X2 in the amount of 12,833 . Therefore $\chi^{2}$ stat $<\chi^{2}$ table $(10,67<12,833)$, Zero 
hypothesis $\left(\mathrm{H}_{0}\right)$ is received. It can be concluded that there is no difference between hope frequency and empiric frequency or data spread come from population with normal distribution.

(2) Testing of Data Spread Normality upon Model Development

TABLE 2.

TESTING OF DATA NORMALITY UPON MODEL DEVELOPMENT

\begin{tabular}{|c|c|c|c|c|c|c|c|c|c|}
\hline \multirow{2}{*}{$\begin{array}{l}\text { No } \\
1\end{array}$} & \multirow{2}{*}{$\begin{array}{l}\text { Classification } \\
\overline{\mathrm{X}}_{-3 \mathrm{SD}}-\overline{\mathrm{X}}_{-2 \mathrm{SD}}\end{array}$} & \multicolumn{3}{|c|}{ Interval Class (IC) } & \multirow{2}{*}{$\frac{\mathrm{f}_{\mathrm{O}}}{0}$} & \multirow{2}{*}{$\frac{\mathrm{f}_{\mathrm{e}}}{1,2}$} & \multirow{2}{*}{$\frac{f_{o}-f_{e}}{-1,2}$} & \multirow{2}{*}{$\frac{\left(f_{o}-f_{e}\right)^{2}}{1,44}$} & \multirow{2}{*}{$\begin{array}{l}\frac{\left(\mathrm{f}_{\mathrm{O}}-\mathrm{f}_{\mathrm{e}}\right)^{2}}{\mathrm{f}_{\mathrm{e}}} \\
1,20\end{array}$} \\
\hline & & 5,59 & - & 6,68 & & & & & \\
\hline 2 & $\bar{X}_{-2 S D}-\bar{X}_{-1 S D}$ & 6,68 & - & 7,76 & 8 & 8,4 & $-0,4$ & 0,16 & 0,02 \\
\hline 3 & $\overline{\mathrm{X}}_{-1 \mathrm{SD}}-\overline{\mathrm{X}}$ & 7,76 & - & 8,85 & 12 & 20,4 & $-8,4$ & 70,56 & 3,46 \\
\hline 4 & $\overline{\mathrm{X}}-\overline{\mathrm{X}}_{+1 \mathrm{SD}}$ & 8,85 & - & 9,94 & 24 & 20,4 & 3,6 & 12,96 & 0,64 \\
\hline 5 & $\overline{\mathrm{X}}_{+1 \mathrm{SD}}-\overline{\mathrm{X}}_{+2 \mathrm{SD}}$ & 9,94 & - & 11,02 & 15 & 8,4 & 6,6 & 43,56 & 5,19 \\
\hline 6 & $\overline{\mathbf{X}}_{+2 \mathrm{SD}}-\overline{\mathbf{X}}_{+3 \mathrm{SD}}$ & 11,02 & - & 12,11 & 1 & 1,2 & $-0,2$ & 0,04 & 0,03 \\
\hline \multicolumn{5}{|c|}{ Total } & 60 & 60 & & & 10,53 \\
\hline
\end{tabular}

From the analysis result is gained $\chi^{2}$ stat in the amount of 10,53 while $\chi^{2}$ table part of $\mathrm{df}=6-1=5$ and significance standard $2,5 \%$ shows $\chi^{2}$ in the amount of 12,833 . Therefore $\chi^{2}$ stat $<\chi^{2}$ table $(10,53<12,833)$. Hence, zero hypothesis $\left(\mathrm{H}_{0}\right)$ is received so that it can be concluded that there is no difference between hope frequency and empiric frequency or data spread come from the population with normal distribution.

(3) Testing of research variant homogeneity, with the following formulation

$$
\begin{aligned}
\mathbf{F} & =\frac{\text { the biggest variant }}{\text { the smallest variant }} \\
& =\frac{1,26}{1,18} \\
& =1,065
\end{aligned}
$$

From the analysis result it was gained that Fmax $=$ Fstat in the amount of 1,065 while Ftable on significance $1 / 2 \alpha=$ 0,025 with $\mathrm{df}=59,59$ was 1,674 . This means Fstat $<\mathrm{F}(0,025,29,29)$ or $1,065<1,674$. Hence $\mathrm{H}_{0}$ is received, so that can be concluded that there is variant difference of each group or both group come from population that has homogeny variant.

(4) Testing of research significance 
TABLE 3.

TABLE OF SigNIFICANCE TESTING

\begin{tabular}{|c|c|c|c|c|c|}
\hline No & $\mathrm{X}_{1}$ & $\mathrm{X}_{2}$ & $\mathrm{~d}$ & $\mathrm{~d}-\overline{\mathrm{d}}$ & $(\mathrm{d}-\overline{\mathrm{d}})^{2}$ \\
\hline 1. & 5 & 8 & 3 & $-2,07$ & 4,27 \\
\hline 2. & 4 & 8 & 4 & $-1,07$ & 1,14 \\
\hline 3. & 3 & 9 & 6 & 0,93 & 0,87 \\
\hline 4. & 4 & 9 & 5 & $\begin{array}{c}-0,07 \\
\end{array}$ & 0,00 \\
\hline 5. & 3 & 9 & 6 & 0,93 & 0,87 \\
\hline 6. & 3 & 9 & 6 & 0,93 & 0,87 \\
\hline 7. & 3 & 10 & 7 & 1,93 & 3,74 \\
\hline 8. & 5 & 9 & 4 & $-1,07$ & 1,14 \\
\hline 9. & 7 & 7 & 0 & $-5,07$ & 25,67 \\
\hline 10. & 3 & 8 & 5 & $-0,07$ & 0,00 \\
\hline 11. & 3 & 9 & 6 & 0,93 & 0,87 \\
\hline 12. & 3 & 8 & 5 & $-0,07$ & 0,00 \\
\hline 13. & 4 & 11 & 7 & 1,93 & 3,74 \\
\hline 14. & 3 & 8 & 5 & $-0,07$ & 0,00 \\
\hline 15. & 5 & 9 & 4 & $-1,07$ & 1,14 \\
\hline 16. & 7 & 10 & 3 & $-2,07$ & 4,27 \\
\hline 17. & 3 & 10 & 7 & 1,93 & 3,74 \\
\hline 18. & 3 & 7 & 4 & $-1,07$ & 1,14 \\
\hline 19. & 3 & 10 & 7 & 1,93 & 3,74 \\
\hline 20. & 3 & 12 & 9 & 3,93 & 15,47 \\
\hline 21. & 6 & 9 & 3 & $-2,07$ & 4,27 \\
\hline 22. & 5 & 9 & 4 & $-1,07$ & 1,14 \\
\hline 23. & 3 & 9 & 6 & 0,93 & 0,87 \\
\hline 24. & 3 & 10 & 7 & 1,93 & 3,74 \\
\hline 25. & 4 & 10 & 6 & 0,93 & 0,87 \\
\hline 26. & 4 & 7 & 3 & $-2,07$ & 4,27 \\
\hline 27. & 3 & 9 & 6 & 0,93 & 0,87 \\
\hline 28. & 3 & 9 & 6 & 0,93 & 0,87 \\
\hline 29. & 3 & 9 & 6 & 0,93 & 0,87 \\
\hline 30. & 4 & 10 & 6 & 0,93 & 0,87 \\
\hline 31. & 3 & 9 & 6 & 0,93 & 0,87 \\
\hline 32. & 5 & 8 & 3 & $-2,07$ & 4,27 \\
\hline 33. & 3 & 10 & 7 & 1,93 & 3,74 \\
\hline 34. & 3 & 7 & 4 & $-1,07$ & 1,14 \\
\hline 35. & 3 & 9 & 6 & 0,93 & 0,87 \\
\hline 36. & 4 & 9 & 5 & $-0,07$ & 0,00 \\
\hline 37. & 3 & 10 & 7 & 1,93 & 3,74 \\
\hline 38. & 3 & 10 & 7 & 1,93 & 3,74 \\
\hline 39. & 6 & 9 & 3 & $-2,07$ & 4,27 \\
\hline 40. & 4 & 9 & 5 & $-0,07$ & 0,00 \\
\hline 41. & 3 & 7 & 4 & $-1,07$ & 1,14 \\
\hline 42. & 3 & 9 & 6 & 0,93 & 0,87 \\
\hline 43. & 3 & 8 & 5 & $-0,07$ & 0,00 \\
\hline 44. & 4 & 8 & 4 & $-1,07$ & 1,14 \\
\hline 45. & 3 & 10 & 7 & 1,93 & 3,74 \\
\hline 46. & 5 & 9 & 4 & $-1,07$ & 1,14 \\
\hline 47. & 4 & 10 & 6 & 0,93 & 0,87 \\
\hline 48. & 6 & 7 & 1 & $-4,07$ & 16,54 \\
\hline 49. & 3 & 8 & 5 & $\begin{array}{l}-0,07 \\
\end{array}$ & 0,00 \\
\hline 50. & 3 & 10 & 7 & 1,93 & 3,74 \\
\hline 51. & 5 & 10 & 5 & $-0,07$ & 0,00 \\
\hline 52. & 3 & 8 & 5 & $\begin{array}{l}-0,07 \\
\end{array}$ & 0,00 \\
\hline 53. & 3 & 9 & 6 & 0,93 & 0,87 \\
\hline 54. & 5 & 7 & 2 & $-3,07$ & 9,40 \\
\hline 55. & 3 & 7 & 4 & $-1,07$ & 1,14 \\
\hline 56. & 6 & 9 & 3 & $-2,07$ & 4,27 \\
\hline 57. & 4 & 9 & 5 & $-0,07$ & 0,00 \\
\hline 58. & 3 & 8 & 5 & $-0,07$ & 0,00 \\
\hline 59. & 3 & 8 & 5 & $-0,07$ & 0,00 \\
\hline 60. & 3 & 9 & 6 & 0,93 & 0,87 \\
\hline Total & 77 & 180 & 5,07 & $-2,07$ & 4,27 \\
\hline n & 60 & & & $-1,07$ & 1,14 \\
\hline
\end{tabular}

Based on table 3 above, t-test score is counted using the correlating sample with the following formula. 


$$
\begin{gathered}
\mathrm{t}=\frac{\overline{\mathrm{X}} \mathrm{d}}{\sqrt{\frac{\sum\left(\mathrm{X}_{\mathrm{d}}-\overline{\mathrm{X}}_{\mathrm{d}}\right)^{2}}{\mathrm{n}(\mathrm{n}-1)}}} \\
\mathrm{t}=\frac{5.07}{\sqrt{\frac{72.7}{60(60-1)}}=35,36 \quad \text { Obtained: }} \quad \begin{array}{l}
\mathrm{t}_{\text {table }}=2,3 \\
t_{\text {stat }}=35,36
\end{array}
\end{gathered}
$$

Based on the analysis result above, it was obtained that $t_{\text {stat }}>\mathrm{t}$ table. Thus, it can be concluded that there was a significant difference between predevelopment and postdevelopment of NSM and Semantic Field-based Balinese langauge vocabulare learning materials development for grade 1, 2 and 3 Elementary school students.

\section{Discussion}

Quantitatively, this research result shows that there is a significance learning result difference between before and after the implementation of NSM theory and semantic field on vocabulary teaching. The reliable NSM theory for vocabulary learning is based on the universality of semantics primes. Semantic prime is the first semantic element that is mastered on its language acquisition period, so the teaching becomes more natural. Semantic prime is semantic core that can be developed by collocation principal and set that become part of semantic field theory. Development of semantic core with meaning field principal gives an ease to the Elementary Students grade 1, 2, and 3 who are not skilled to think implicitly. The ease is embodied as the presence of comparison of lexical semantic features which can be comprehended by students. The presence of comparison can directly reduce vagueness and abstraction of word meaning that has been becoming students' cognitive burden.

Apart from theoretical implication mentioned above, NSM theory implementation and semantic field also contributes pragmatically because vocabulary as learning materials was collected based on natural condition of Balinese language so that it has a high practicability value. Vocabulary taught is adjusted with linguistic need and cognitive development level of Elementary Students grade 1, 2, and 3, which exist at the end of preoperational phase and enter the beginning of concrete operational phase. Cognitive development in this phase needs 'real reconciliation' as the result of limitedness in abstracting a concept. The real reconciliation can be explicated by semantic comparison that is presented in a meaning field. Hence, a correct NSM and semantic field application in Balinese vocabulary learning on Elementary Student grade 1, 2, and 3 can omit the prescriptive vocabulary teaching.

\section{CONCLUSION}

Based on analysis result, it was proved that NSM theory and semantic field is very effective to implement on Balinese vocabulary learning for Elementary Students grade 1, 2, and 3. This conclusion was made because point $t_{\text {stat }}$ $(35,36)$ was much larger than point of t-table $(2,3)$. Another fact that supports this conclusion is the improvement of learning effectiveness. Before the implementation of NSM theory and semantic field, the effectiveness of Balinese vocabulary learning only reached $31,5 \%$ with speed level of word meaning understanding $(36,0 \%)$, the use of skill in sentence was in the amount of $28,8 \%$, and student learning creativity was $29,6 \%$. Upon NSM theory and semantic field implementation, the effectiveness of Balinese vocabulary learning increase to $73,8 \%$ with some indicators, such as (1) speed of word meaning understanding $(71,7 \%)$, (2) students' skill of using words in sentence raised to 73,8\%, and (3) student learning creativity increased to $75,8 \%$. Learning effectiveness increase occurred because material choice was consistent with nature language acquisition principal, as it has been lined by NSM theory and determined the needs and language competence of the students. Another factor that supported learning effectiveness increasing was the presence of inter word semantic comparison in a meaning field in semantics primes frame.

\section{REFERENCES}

[1] Alwi, Hasan dan Dendy Sugondo. (2003). Politik Bahasa : Rumusan Seminar Politik Bahasa. Jakarta: Pusat Bahasa Departemen Pendidikan Nasional.

[2] Arnawa, Nengah. (2005). Bahasa Bali Usia Anak-anak: Kajian Metabahasa Semantik Alami. Doctoral disertation. Udayana University, Denpasar.

[3] Borg, W.R. dan Gall, M.D. (1983). Educational Research. Boston: Pearson Education.

[4] Chaer, Abdul. (2003). Psikolinguistik: Kajian Teoretik. Jakarta: Rineka Cipta.

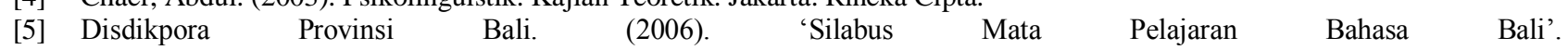
http://www.scribd.com/mobile/document/328292974/Silabus-Bahasa-Bali (acessed, 20 July 2008).

[6] Goddard, C. (1996). "Semantic Theory and Semantic Universal". In Cliff Goddard (Conventor), Cross- Linguistic Synatx from a Semantic Point of View (MSA Approach), 1- 5. Australia: Australian National University.

[7] Goddard, C. (1997). Semantic Analysis : A Practical Introduction. Oxford : Oxford University Press.

[8] Harimurti, Kridalaksana. (1993). Kamus Linguistik. Jakartra: Gramedia Pustaka Utama. 
[9] Krashen, Stephen D dan Tracy D. Terrell. (1983). The Natural Approach Language Aquisition in the Classroom. New York: Pergamon Press.

[10] Owens. Jr. R.E. (1992). Langauge Development : An Introduction. New York : Macmillan Publishing Company.

[11] Parera, J.D. (1990). Teori Semantik. Jakarta: Erlangga.

[12] Pemerintah Provinsi Bali. (1992). 'Peraturan Daerah Nomor 3 Tahun 1992 tentang Bahasa, Aksara, dan Sastra Bali'. http://jdih.baliprov.go.id/uploads/produk/1992/Perda_1992_3.doc (acessed, 17 March 2005).

[13] Pemerintah Provinsi Bali. (2013). Peraturan Gubernur Bali Nomor 20 Tahun 2013 tentang Bahasa, Aksara, dan Satra Daerah Bali pada Pendidikan Dasar dan Menengah. http://jdihbirohukuham.baliprov.go.id/uploads/produk/2013/PERGUB/_20_2013.docx (acessed, 6 August 2014).

[14] Sugiyono. (2012). Metode Penelitian Pendidikan: Pendekatan Kuantitatif, Kualitatif, dan R\&D. Bandung: Alfabeta.

[15] Sujiono, Yuliani Nurani dkk. (2006). Metode Pengembangan Kognitif. Jakarta : Open University.

[16] Sumarsono. (2004). Filsafat Bahasa. Jakarta: Grasindo.

[17] Sumatika, Wayan. (2008). Mencetak Penutur Bahasa Bali: Menyelamatkan Bahasa Bali. Bali Post. http://sastrapembebasan.10929.n.7nable.com/satra-pembebasan-quot-Rahina-Mabasa-Bali-quot-Mencetak-Penutur-Baru-MenyelematkanBahasa-Bali-td26404 (acessed, 12 October 2014).

[18] Sund, R. B. (1976). Piaget for Educators : A Multimedia Program. Ohio: Charles E. Merril Publishing Company.

[19] Tarigan, H.G. (1986). Pengajaran Kosakata. Bandung: Angkasa.

[20] Warna,dkk. I Wayan. (1978). Kamus Bali - Indonesia. Denpasar: Dinas Pengajaran Provinsi Bali.

[21] Wierzbicka, Anna. (1996). Semantics : Primes and Universals. Oxford : Oxford University Press.

[22] Wierzbicka, A (1996b). "Cultural scripts : a new approach to study of cross culture communication". In Anna Wierzbicka (Conventor), Cross-Culture Communication, 1 - 10. Australia : Australian National University.

[23] Wiguna, I Wayan Alit Artha. dkk. (2015). Jasa Lingkungan Budaya Sistem Subak di Bali. Denpasar: Yayasan Somia Pertiwi Bali dan Fauna \& Flora International United Kingdom.

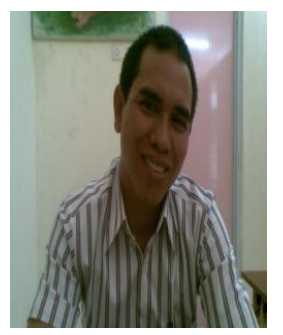

Nengah Arnawa was born in Jinengdalem, Singaraja, Bali, Indonesia on 24 Desember 1965. He pursued Bachelor in Language and Art Education from Faculty of Education Udayana University, Singaraja. He was awarded scholarship for master program in Linguistics in 1998 and completed the program in 2000 at Udayana University, Denpasar. He then pursued scholarship and joined doctorate program in Linguistic, Udayana University in 2002 and completed the program in 2005. His fields of interest include semantics and pragmatics.

He has dedicated himself as lecturer at Faculty of Language and Art Education IKIP PGRI Bali since 1990.

His career in the institution included Deputy Dean I from 2002-2009, and Dean of Faculty of Language and Art Education IKIP PGRI Bali from 2011-2015. He was awarded as lector kepala in Indonesian Language Semantic since 1 November 2002. He has been writing a number of articles in the field of semantics and pragmatics, including Meaning Truth Explication Language Philosophy: A Multicultural Communication Dimension (2015); Children Indirect Speech Acts at Ages 18-24 Month Old: A Case Studi on Indonesian Language Acquisition by Balinese Children (2016); Shift of Balinese Language Vocabulary of Agriculture: A Study on Antrophological Linguistics (2016). In 2017 - 2018, he is still undertaking a research in Hegemonic Politeness of Balinese Language in Awig-Awig (Traditional Rule of Bali), granted by Directorate of General of Higher Education, Ministry of Research, Technology and Higher Education.

Dr. Nengah Arnawa, M.Hum. is also active in some memberships, including "Masyarakat Linguistik Indonesia" (MLI) (Indonesian Linguistic Society); “Asosiasi Peneliti Bahasa Lokal” (APBL) (Association of Local Languages Researcher), and one of committee members in "Asosiasi Pengelola Program Studi Bahasa dan Sastra Indonesia” (Association of Management of Indonesia Language and Literature Study Program). 